\title{
Avoiding the poverty pandemic: the potential of the Bolsa Familia program and the Single Registry for Social Programs to face the COVID-19 pandemic
}

\author{
Luis Henrique Paiva 1 \\ Pedro H. G. Ferreira de Souza ${ }^{1}$ \\ Letícia Bartholo 1 \\ Sergei Soares ${ }^{1}$ \\ ${ }^{1}$ Instituto de Pesquisa Econômica Aplicada / Directorate for Social Studies and Policies, Brasília / DF - Brazil
}

\begin{abstract}
This study suggests three measures to enhance the potential of the Bolsa Familia program and Single Registry for Social Protection (Cadastro Unico) as responses to the economic consequences of the COVID-19 pandemic. We propose to: (i) enroll all eligible households already in the Cadastro Único in the Bolsa Família program, and postpone all verification and recertification processes that could result in benefit cuts; (ii) adjust the eligibility thresholds of Bolsa Família and the value of the benefits; and (iii) grant an emergency benefit, for at least six months, to all families enrolled in the Single Registry (regardless of whether they are Bolsa Família beneficiaries or not) whose per capita income is below half a minimum wage. The combination of these measures results in 56 different scenarios. Based on the data from the Single Registry and the Bolsa Familia payroll, the study estimates the target audience and costs. Given the unprecedented magnitude of these measures, the study also emphasizes possible institutional and operational difficulties for their implementation. A combination of these measures is recommended, with a duration of at least six months.
\end{abstract}

Keywords: COVID-19; poverty; Bolsa Família; Cadastro Único.

\section{Evitando a pandemia da pobreza: possibilidades para o programa Bolsa Família e para o Cadastro Único em resposta à COVID-19}

Neste estudo propomos três medidas para potencializar o uso do Programa Bolsa Família e do Cadastro Único para Programas Sociais (Cadastro Único) como resposta às consequências econômicas da pandemia da COVID-19. As medidas propostas são as seguintes: (i) zerar a fila de espera do Programa e suspender procedimentos que possam levar à cessação de benefícios; (ii) reajustar benefícios e linha de elegibilidade do Programa; e (iii) conceder um benefício extraordinário para todas as famílias do Cadastro Único, beneficiárias ou não do Bolsa Família. As combinações para as alternativas destas medidas resultam em 56 cenários com parâmetros únicos, para os quais, com base nos dados do Cadastro Único e na folha de pagamentos do Bolsa Família, estimam-se o público alvo e os custos. Também avaliamos as eventuais dificuldades institucionais e operacionais para a implementação destas medidas, já que as iniciativas podem ter uma magnitude inédita na política social brasileira. Recomendamos uma combinação relativamente generosa destas medidas, por um período de pelo menos seis meses. Palavras-chave: COVID-19; pobreza; Bolsa Família; Cadastro Único.

\section{Evitando la pandemia de la pobreza: posibilidades para el "Programa Bolsa Família" y el Registro Único en respuesta a la COVID-19}

Este estudio propone tres medidas para potenciar el uso del "Programa Bolsa Família” y del Registro Único (Cadastro Único) para Programas Sociales como respuestas a las consecuencias económicas de la pandemia de COVID-19. Se propone (i) reducir a cero la lista de espera del programa y posponer los procedimientos administrativos que podrían resultar en recortes de beneficios; (ii) reajustar el umbral de elegibilidad y el valor de los beneficios del "Bolsa Família"; y (iii) otorgar un beneficio de emergencia, por al menos seis meses, a todas las familias inscritas en el Registro Único (sean o no beneficiarias del "Bolsa Família”) cuyo ingreso per cápita sea inferior a la mitad del salario mínimo. Las combinaciones de las alternativas de estas medidas dan como resultado 56 escenarios diferentes. Sobre la base de los datos del Registro Único y la nómina del “Bolsa Família”, el estudio estima el público objetivo y los costos de las medidas propuestas. Dada la magnitud sin precedentes de estas medidas, el estudio también evalúa las posibles dificultades institucionales y operativas para su implementación. Se recomienda una combinación relativamente generosa de estas medidas por un período de al menos 6 meses.

Palabras clave: COVID-19; pobreza; Bolsa Família; Cadastro Único. 


\section{INTRODUCTION}

The goal of this paper is to propose ways to potentialize the use of the Bolsa Familia programme (Programa Bolsa Família-PBF) and of the Single Registry for Social Programs (Cadastro Único) as mechanisms to reduce the economic and social impacts of the COVID-19 pandemic. The proposals were designed through a combination of measures, resulting in 56 different simulations.

Conditional cash transfers (a type of programme that includes Bolsa Familia) emerged in Brazil in the early 1990s at the local level and gained nationwide coverage in the early 2000s, alongside the Single Registry - the main administrative record of Brazilian programmes directed at low-income households (Lindert, Linder, Hobbs, \& De La Brière, 2007; Paiva, Cotta, \& Barrientos, 2019).

Bolsa Familia's targeting and impacts on poverty have been studied extensively. The conclusions can be summarised as follows: the programme is the Brazilian federal government's most progressive transfer (i.e. the one that contributes the most to the reduction of inequality) (Hoffman, 2013; Instituto de Pesquisa Econômica Aplicada [IPEA], 2012). Its introduction led to evidence of rupture in the cycle of poverty (Pena, Pinheiro, Albuquerque, \& Fernandes, 2015) and its impacts on the reduction of extreme poverty are limited only by the low value of transfers (Osorio, Soares, \& Souza, 2011; Paiva, Souza, \& Nunes, 2020).

These characteristics mark the Bolsa Familia and the Single Registry as unparalleled instruments in the mitigation of the economic - and therefore social -impacts of the COVID-19 pandemic. The Brazilian Institute of Economics of the Getúlio Vargas Foundation (FGV IBRE) estimates the drop in gross domestic product (GDP) and in the income of households for 2020 in the country at 3.4 per cent and 4 per cent, respectively (FGV IBRE, 2020). However, the decrease in GDP is constantly being adjusted by both the government and the market at large: in its Microfiscal Bulletin released in 13 May, the Economic Policy Bureau (Secretaria de Politica Econômica) of the Ministry of Economics estimated the drop in GDP at 4.7 per cent. On the other hand, the market - as recorded by the Focus-Market Report of 15 May (Banco Central do Brasil [Bacen], 2020) - registered a GDP forecast of -5.12 per cent (against a previous forecast of 2.96 per cent released four weeks prior). The labour market indicators of the Continuous National Household Sample Survey (PNAD Contínua/ Instituto Brasileiro de Geografia e Estatística - IBGE) that were released for the first quarter have not yet captured the impacts of the economic crisis on unemployment and income, but the current evidence highlighted by the media suggests that we are facing a deep and intense economic crisis, with potentially devastating social effects.

Before moving forward, there are three crucial considerations to keep in mind. First, there precedents and both local and international levels for the use of cash transfer programmes as a response to humanitarian emergencies. The social rent paid to people who lost their homes during the floods in January 2011 and the extra benefit paid to residents of Brumadinho (in the state of Minas Gerais) after the dam disaster in January 2019 are local examples. An ongoing mapping by World Bank economist Ugo Gentilini (2020) illustrates that 60 countries are already using some kind of cash transfer as part of their response to COVID-19. In other words, cash transfers are being considered internationally as a crucial measure to mitigate the increase in structural and temporary poverty resulting from the pandemic.

Second, the suggestions presented here are based on the operational model currently in place for the Bolsa Família and the Single Registry. This implies that these recommendations encompass over 
30 per cent of the Brazilian population, whose monthly household income is below half a minimum wage per capita (BRL522.50).

Third, any answer to COVID-19 that involves financial support to poor, low-income households must consider institutional and operational difficulties. This is the criterion we have adopted: all our policy recommendations are for viable implementation during this critical period, and we present proposals in increasing order of institutional and operational difficulty.

Therefore, this work is organised as follows: Section 2 presents the simulation of the three policy measures; Section 3 describes in further detail the main simulated scenarios and reports the findings in terms of coverage and costs; and Section 4 indicates our recommended scenarios among the 56 simulations. Finally, the Annex presents the figures obtained for each of the simulations.

\section{CRITERIA AND INTERVENTION SCENARIOS}

We present three policy measures, two of which include more than one simulated scenario.

\section{A. Enrol all eligible households already in the Cadastro Único in Bolsa Família and postpone all verification and recertification processes.}

This is an essential measure for two reasons: first, it ensures income protection to all households that have already registered and have been waiting for months to enter the Bolsa Familia programme; second, it prevents people from reaching out to the social assistance reference centres (Centros em Referência de Assistência Social - CRAS) to update their Single Registry information. As the CRAS will already face significant pressure during the crisis, being in the frontlines, there is a pressing epidemiological need to avoid public gatherings in these spaces.

B. Adjust the eligibility threshold and the value of Bolsa Familia benefits.

As there is no indexing in Bolsa Familia, the real value of eligibility thresholds and of the benefits depends on discretionary adjustments, which generally have not been made with enough regularity or intensity to maintain the purchasing power of households.

C. Create an emergency benefit, for at least six months, for all households enrolled in the Single Registry (whether Bolsa Família beneficiaries or not) whose per capita income is below half a minimum wage.

Given the need for social distancing and to avoid mass gatherings, granting temporary benefits to vulnerable households is a more rational preventive measure than simply waiting for them to fall into poverty and having to seek out a CRAS to update their Single Registry information. Households with up-to-date registration information and with a per capita income below half a minimum wage - even if they are not Bolsa Família beneficiaries - are in great risk of falling into poverty and, therefore, need a temporary emergency benefit. Households that are already enrolled in the programme would receive both the standard benefit and the emergency benefit.

Simulations were carried out based on data from the Single Registry that was current up to December 2018 and the Bolsa Familia payroll up to January 2019.

The extracts of the Single Registry, carried out monthly by Caixa Econômica Federal (Caixa) and by the Ministry of Citizenship, are the most complete administrative record for studies on social policies. The Single Registry captures a broad set of personal data (documentation, schooling level, work and income), as well as household data (household composition, characteristics, access to public 
utilities, etc.), which are crucial for the implementation and management of social policies across all three levels of the federation (municipal, state and federal).

Due to its characteristics, the Single Registry is the most precise source of information for estimating the budget impacts of altering policies based on it, such as what we are proposing in this work. As we have access to the entire universe of actual or potential beneficiaries, and the records undergo very slow changes over time, these estimates tend to be quite precise.

In the Bolsa Família payroll for January 2019, there were 13.76 million households and 42.73 million people. If we add to that figure non-beneficiaries with Single Registry information that was up to date as of December 2018, we have 21.14 million households and 63.60 million people.

The exercises carried out in the next Section consisted mainly in estimating, based on the microdata described above, (i) non-beneficiary households that fit the Programme's eligibility criteria and (ii) the cost of granting the benefits of the Programme (Measures A and B) and of the emergency benefit (Measure C). We have considered the current eligibility criteria (for Measure A) and proposed eligibility criteria (for Measures B and C).

The estimates obtained were compared to the baseline scenario, so that the reader can have a precise notion of the fiscal effort needed to implement each of the measures as well as their combinations. Section 3 presents some of these combinations, and the Appendix presents all estimates for each of the 56 scenarios.

\section{SCENARIOS BASED ON THE BOLSA FAMÍLIA STRUCTURE}

\subsection{Policy measure A: Enrol all eligible households in Bolsa Familia and postpone verification and recertification processes}

Bolsa Família has a waiting list of approximately 1.7 million households. We estimate that granting benefits to all eligible households in the Single Registry would expand the programme to almost 15.5 million households.

If this measure had been adopted in April and extended until the end of the year, its budget impact would be around BRL2.24 billion, an increase of almost 10 per cent against the current scenario (see Table 1). With BRL3 billion, it will probably be possible to postpone verification and recertification processes (and therefore blockages, suspensions and cancellations of benefits) over the next few months.

\section{TABLE 1 COVERAGE AND COST OF MEASURE A}

\begin{tabular}{lcccccccc} 
& \multicolumn{2}{c}{ Coverage (millions) } & Average benefit & \multicolumn{2}{c}{ Cost (BRL billion) } & \multicolumn{3}{c}{ Total variation } \\
Scenario & Households & People & $\begin{array}{c}\text { per household } \\
\text { (BRL) }\end{array}$ & $\begin{array}{c}\text { Per } \\
\text { month }\end{array}$ & Total & $\begin{array}{c}\text { Absolute } \\
\text { (BRL billion) }\end{array}$ & $\begin{array}{c}\text { Relative } \\
(\%)\end{array}$ \\
\hline Current scenario & 13.8 & 42.7 & 188 & 2.586 & 23.273 & - & - \\
A. No waiting list & 15.5 & 47.7 & 183 & 2.835 & 25.513 & 2.240 & 9.6 \\
\hline
\end{tabular}

Note: Total cost represents the nine remaining months of 2020 (April-December).

Source: Elaborated by the authors based on the Single Registry (December 2018) and the Bolsa Família payroll (January 2019). 
Level of institutional difficulty: Virtually non-existent. The concession is simply an administrative decision, as is delaying the assessment and review processes.

Level of operational difficulty: The issuance and distribution of electronic cards already falls within the established operational procedures, but the scale is unusual (1.7 million), which requires special attention. Withdrawals can be made directly by presenting a slip directly to Caixa bank tellers, providing individual identification, but this option is perhaps not advisable from an operational and/or public health standpoint.

\subsection{Measure B: Adjusting the eligibility thresholds and the value of the benefits}

For measure B, we present three adjustment scenarios.

B1) By a percentage that sets the two eligibility thresholds at their historical average value. The extreme poverty line would be set at BRL105, the same value as the basic benefit and the reference value used to calculate the benefit for overcoming extreme poverty (Benefício de superação da pobreza extrema - BSP); the poverty line would increase to BRL210; variable benefits for pregnant and nursing women and children would increase to BRL48, and the variable benefit for adolescents (BJV) would increase to BRL57. These values represent an increase of approximately 18 per cent.

B2) By a percentage that brings eligibility thresholds back to the real value they had in January 2004. The extreme poverty line would increase to BRL115, the same value as the basic benefit and the reference value for the BSP; the poverty line would rise to BRL230; the variable benefit would rise to BRL53, and the BVJ would reach BRL62. These values represent an increase of around 29 per cent.

B3) By a percentage that brings the eligibility thresholds back to the real value of their historical peak, observed in August 2009. The extreme poverty line would increase to BRL125, as would the value of the basic benefit and of the reference for the BSP calculation; the poverty line would increase to BRL250; variable benefits would reach BRL58, and the BVJ would reach BRL67. The budget increase from this adjustment would be around 41 per cent. Even with this adjustment, Bolsa Família's extreme poverty line would remain below the international threshold of USD1.90/day in purchasing power parity (PPP) terms - approximately BRL150 per month - used by the World Bank, whose reference is the national poverty lines of some of the world's poorest countries.

The adjustment of thresholds and benefit values would impact the budget in two ways. First, it would increase the number of eligible households; second, it would increase the value of the benefits. In Table 2 we present the full impact of measure B - that is, the inclusion of all eligible households according to the new eligibility thresholds, as well as the effective costs of increasing the benefits. This can be understood as the combined impacts of measures A and B. The independent impact of the scenarios detailed for measure B can be found in the Annex.

Scenarios AB1-AB3 would increase the number of Bolsa Família beneficiaries by between 17 per cent and 21 per cent, while the average benefit per household would increase by between 15 per cent and 38 per cent. In scenario AB3, almost 3 million families would be added to Bolsa Família; in other words, the programme's protection would be extended to almost 9 million people currently not covered. 
Therefore, the cost would be between around BRL8 billion (scenario AB1) and BRL15.6 billion (scenario AB3). The intermediary alternative would imply an expenditure of BRL11.6 billion. The Programme's cost for the remainder of the year (from April to December) would be between one and two thirds higher than in the current scenario.

TABLE 2 COVERAGE AND COSTS FOR THE SCENARIOS IN MEASURE B, COMBINED WITH MEASURE A

\begin{tabular}{|c|c|c|c|c|c|c|c|}
\hline \multirow[b]{2}{*}{ Scenario } & \multicolumn{2}{|c|}{ Coverage (millions) } & \multirow{2}{*}{$\begin{array}{l}\text { Average benefit } \\
\text { per household } \\
\text { (BRL) }\end{array}$} & \multicolumn{2}{|c|}{ Cost (BRL billion) } & \multicolumn{2}{|c|}{ Total variation } \\
\hline & Households & People & & Per month & Total & $\begin{array}{l}\text { Absolute } \\
\text { (BRL billion) }\end{array}$ & Relative (\%) \\
\hline Current scenario & 13.8 & 42.7 & 188 & 2.586 & 23.273 & - & - \\
\hline $\begin{array}{l}A+B 1: 17-19 \% \\
\text { adjustment }\end{array}$ & 16.0 & 49.5 & 217 & 3.474 & 31.265 & 7.992 & 34.3 \\
\hline $\begin{array}{l}\text { A + B2: Approx. 29\% } \\
\text { adjustment }\end{array}$ & 16.2 & 50.1 & 239 & 3.873 & 34.856 & 11.583 & 49.8 \\
\hline $\begin{array}{l}A+B 3: 40-41 \% \\
\text { adjustment }\end{array}$ & 16.6 & 51.6 & 260 & 4.314 & 38.826 & 15.553 & 66.8 \\
\hline
\end{tabular}

Note: Total cost represents the nine remaining months of 2020 (April-December).

Source: Elaborated by the authors based on the Single Registry (December 2018) and the Bolsa Família payroll (January 2019).

Level of institutional difficulty: Low. The eligibility thresholds and the value of the benefits can be adjusted by presidential decree. There is no need for legislative change.

Level of operational difficulty: There is no operational difficulty for beneficiary households. The inclusion of new households implies the issuance and distribution of cards, as discussed above. There is a potential for conflict, but the operational process is already well defined.

\subsection{Measure C: Create a temporary emergency benefit for all households enrolled in the Single Registry whose per capita income is under half a minimum wage}

Measure $\mathrm{C}$ entails the creation of an emergency benefit paid to all Bolsa Família beneficiary households (which would continue to receive their regular benefits), as well as to all other households enrolled in the Single Registry whose information has been updated, and whose per capita income is below half a minimum wage - that is, BRL522.50.

We have simulated six different values for the emergency benefits with a duration of six months:

C1) BRL150 per household;

C2) BRL300 per household;

C3) BRL450 per household;

C4) BRL50 per capita;

C5) BRL100 per capita;

C6) BRL150 per capita. 
With this emergency benefit, a greater number of people would then be able to count on some income at a time of a great negative shock to the economy. If the social crisis caused by the COVID-19 outbreak lasts longer than predicted, the emergency benefit could and should be extended for as long as deemed necessary.

Table 3 first presents the results of the simulation of scenarios C1 through C6, in combination with measure A. Specific results for scenarios C1 to C6 are available in the Annex.

The scenarios simulated in Table 5 present greater coverage than any of the previous simulations, as the emergency benefits would be paid to all 21.1 million households with a per capita income below half a minimum wage that are registered in the Single Registry. ${ }^{1}$ Given these scenarios, the coverage of the emergency benefit would increase by around 50 per cent, extending a minimum level of social protection to around 63.3 million people - or slightly over 30 per cent of Brazil's population.

Given that households in the Single Registry have three members on average, the simulated emergency benefit levels imply budget levels for scenarios $\mathrm{C} 1$ to $\mathrm{C} 3$ and $\mathrm{C} 4$ to $\mathrm{C} 6$ that are very similar. In principle, scenarios $\mathrm{C} 4$ to $\mathrm{C} 6$ seem fairest, as they transfer benefits with the same per capita value to all households (i.e. higher values for larger households). However, there is a risk of significant operational difficulties in the implementation of a benefit of this kind with the current structure. We will return to this discussion later.

In any case, the average benefit per household would increase significantly. In the most conservative scenarios $(A+C 1$ and $A+C 4)$, the increase would be slightly over 50 per cent. In the more ambitious scenarios $(A+C D 3$ and $A+C 6)$, the increase would be over 210 per cent, with an average benefit of around BRL585 per household.

As there is both an expansion in coverage and an increase in the average value, the relative cost increase over the remaining nine months of the year varies between 91 per cent and 256 per cent, even taking into consideration the temporary nature of the emergency benefit. In absolute terms, the additional cost would be between BRL21 billion and BRL59 billion. Notwithstanding the magnitude of these figures, it is worth highlighting once again that even in the most generous scenario, the total cost of welfare transfers would grow from 0.4 per cent to 1.2 per cent of GDP, a value which is compatible with what is observed in many high-income countries during normal times.

TABLE 3

COVERAGE AND COSTS OF MEASURE C SCENARIOS, COMBINED WITH MEASURE A

\begin{tabular}{|c|c|c|c|c|c|c|c|}
\hline \multirow[b]{2}{*}{ Scenario } & \multicolumn{2}{|c|}{ Coverage (millions) } & \multirow{2}{*}{$\begin{array}{c}\text { Average } \\
\text { benefit per } \\
\text { household } \\
\text { (BRL) }\end{array}$} & \multicolumn{2}{|c|}{ Cost (BRL billion) } & \multicolumn{2}{|c|}{ Total variation } \\
\hline & Households & People & & $\begin{array}{c}\text { Per } \\
\text { month }\end{array}$ & Total & $\begin{array}{c}\text { Absolute } \\
\text { (BRL billion) }\end{array}$ & $\begin{array}{c}\text { Relative } \\
\text { (\%) }\end{array}$ \\
\hline Current scenario & 13.8 & 42.7 & 188 & 2.586 & 23.273 & - & - \\
\hline $\begin{array}{l}\text { A + C1 (BRL150 per } \\
\text { household) }\end{array}$ & 21.1 & 63.6 & 284 & 6.005 & 44.536 & 21.263 & 91.4 \\
\hline
\end{tabular}

\footnotetext{
1 These figures refer to the situation of the Single Registry up to December 2018.
} 


\begin{tabular}{|c|c|c|c|c|c|c|c|}
\hline \multirow[b]{2}{*}{ Scenario } & \multicolumn{2}{|c|}{ Coverage (millions) } & \multirow{2}{*}{$\begin{array}{c}\text { Average } \\
\text { benefit per } \\
\text { household } \\
\text { (BRL) }\end{array}$} & \multicolumn{2}{|c|}{ Cost (BRL billion) } & \multicolumn{2}{|c|}{ Total variation } \\
\hline & Households & People & & $\begin{array}{c}\text { Per } \\
\text { month }\end{array}$ & Total & $\begin{array}{c}\text { Absolute } \\
\text { (BRL billion) }\end{array}$ & $\begin{array}{c}\text { Relative } \\
(\%)\end{array}$ \\
\hline $\begin{array}{l}A+C 2 \text { (BRL300 per } \\
\text { household) }\end{array}$ & 21.1 & 63.6 & 434 & 9.176 & 63.558 & 40.286 & 173.1 \\
\hline $\begin{array}{l}A+C 3 \text { (BRL450 per } \\
\text { household) }\end{array}$ & 21.1 & 63.6 & 584 & 12.346 & 82.581 & 59.309 & 254.8 \\
\hline A + C4 (BRL50 per capita) & 21.1 & 63.6 & 285 & 6.015 & 44.591 & 21.319 & 91.6 \\
\hline A + C5 (BRL100 per capita) & 21.1 & 63.6 & 435 & 9.194 & 63.670 & 40.398 & 173.6 \\
\hline A + C6 (BRL150 per capita) & 21.1 & 63.6 & 585 & 12.374 & 82.749 & 59.476 & 255.6 \\
\hline
\end{tabular}

Note: Total cost represents the nine remaining months of 2020 (April-December). As the emergency benefit is planned for only six months, the total cost considers the monthly cost of six months of each scenario and the expected cost of measure A for the last three months of the year. The average benefit per household was calculated using the monthly cost of each scenario.

Source: Elaborated by the authors based on the Single Registry (December 2018) and the Bolsa Familia payroll (January 2019).

The combination of measures A, B and C yields 18 possible scenarios (three scenarios for measure $B$ times six scenarios for measure $C$ ). For the sake of simplicity, we have opted to consider only the result of the combination of measures $\mathrm{A}, \mathrm{B} 2$ and $\mathrm{C} 1-\mathrm{C} 3$, as measure $\mathrm{B} 2$ is the intermediary point between $\mathrm{B} 1$ and $\mathrm{B} 3$, and the cost of $\mathrm{C} 4, \mathrm{C} 5$ and $\mathrm{C} 6$ are practically identical to those of $\mathrm{C} 1, \mathrm{C} 2$ and C3. The figures for the other combinations are presented in the Annex.

Table 4 depicts the estimates for the selected combinations. The coverage of the scenarios is identical to that of Table 3. Differences are due to the average value of the benefits and their budget impact.

The average benefit would increase by between 77 per cent and 237 per cent. In this last case (scenario A + B2 + C3), each household would receive, on average, around BRL633 for as long as the emergency benefit lasts. In per capita terms, this means an average benefit of BRL210 per person for at least six months, the highest value presented in this brief. After the initial six months, around 4.9 million households would stop receiving any benefit whatsoever, while the remaining households would receive the Bolsa Familia adjusted benefits, with an average value of BRL239 per household (or BRL77 per person).

The cost would vary between BRL30.6 billion (A + B2 + C1) and BRL68.7 billion (A + B2 + C3) up to the end of the year. Compared to the current scenario, all simulations more than double the budget - in the upper limit, almost tripling it. The total cost of transfers (including the months from January to March) would rise from 0.4 per cent to something between 0.8 per cent and 1.4 per cent of GDP. 


\begin{tabular}{|c|c|c|c|c|c|c|c|}
\hline \multirow[b]{2}{*}{ Scenario } & \multicolumn{2}{|c|}{ Coverage (millions) } & \multirow{2}{*}{$\begin{array}{l}\text { Average } \\
\text { benefit per } \\
\text { household } \\
\text { (BRL) }\end{array}$} & \multicolumn{2}{|c|}{ Cost (BRL billion) } & \multicolumn{2}{|c|}{ Total variation } \\
\hline & Households & People & & Per month & Total & $\begin{array}{c}\text { Absolute } \\
\text { (BRL billion) }\end{array}$ & $\begin{array}{c}\text { Relative } \\
\text { (\%) }\end{array}$ \\
\hline Current scenario & 13.8 & 42.7 & 188 & 2.586 & 23.273 & - & - \\
\hline $\begin{array}{l}A+B 2(29 \% \text { adj. })+C 1 \\
(B R L 150 \text { per household })\end{array}$ & 21.1 & 63.6 & 333 & 7.043 & 53.879 & 30.606 & 131.5 \\
\hline $\begin{array}{l}A+B 2(29 \% \text { adj.) }+C 2 \\
\text { (BRL300 per household) }\end{array}$ & 21.1 & 63.6 & 483 & 10.214 & 72.902 & 49.629 & 213.2 \\
\hline $\begin{array}{l}A+B 2(29 \% \text { adj.) }+C 3 \\
\text { (BRL450 per household) }\end{array}$ & 21.1 & 63.6 & 633 & 13.384 & 91.925 & 68.652 & 295.0 \\
\hline
\end{tabular}

Note: Total cost represents the nine remaining months of 2020 (April-December). As the emergency benefits are planned for only six months, the total cost considers the monthly cost of six months of each scenario and the expected cost of measure A $+\mathrm{B} 2$ for the last three months of the year. The average benefit per household was calculated using the monthly cost of each scenario.

Source: Elaborated by the authors based on the Single Registry (December 2018) and the Bolsa Família payroll (January 2019).

Level of institutional difficulty: Intermediate. This measure requires the issuance and approval of a provisional measure. We recommend that this benefit be created by specific legislation, not associated with Bolsa Familia legislation: the emergency benefit would reach a broader audience. Ideally, this benefit should make use of Bolsa Familia's existing operational structure to the extent possible.

Level of operational difficulty: High. Caixa’s Citizen Benefit System (Sistema de Benefícios ao Cidadão - SIBEC) is not prepared to automatically create a benefit of this nature. Creating a benefit outside the Bolsa Família's eligibility thresholds involves defining a new process to select beneficiaries and generating a new payroll.

For operational reasons, we recommend the adoption of the model with a flat value per household, as there is a precedent (the case of Brumadinho). This would reduce any probability of error in the operationalisation of the benefit.

Even if it were possible to generate a payroll starting in April, for payment by the end of the month, the scale of the new benefit would require enormous efforts to issue and distribute millions of cards. This might lead to delays in the effective payment of the benefit.

The possibility for beneficiaries to directly withdraw cash in person at physical Caixa branches should be evaluated in light of COVID-19 containment measures.

Another option would be for Caixa to assess how many of the recipients of the emergency benefit have a bank account at the institution (either a current or a savings account), and instead make a deposit in such cases; or, when appropriate, guide beneficiaries to use an existing citizen's card (former Bolsa Familia beneficiaries; people that might have received some other benefit such as salary allowance or unemployment benefits). Whatever the case, any emergency measure taken beyond the current limits of Bolsa Família would very likely face operational difficulties. 


\section{RECOMMENDATION}

The COVID-19 pandemic presents unprecedented challenges to the Brazilian social protection system. Informal workers, unemployed people and poor households in general are especially exposed to the combination of pandemic and recession. Given the probability of catastrophic consequences from the social point of view, our recommendation tends inevitably towards the more generous scenarios. In the worst-case scenario, even if the social risks are overestimated, the additional expenditure would be almost entirely temporary and would not reach 1.5 per cent of GDP.

In this context, we recommend the implementation of scenario $\mathrm{A}+\mathrm{B} 2+\mathrm{C} 3$ at the very least. In other words, we suggest:

- Include all eligible households already in the Single Registry in the Bolsa Família programme, and suspend verification and recertification processes.

- Permanently adjust Bolsa Família's eligibility thresholds and benefits by approximately 29 per cent.

- The government should create a temporary emergency benefit, with an expected duration of six months but with the possibility of extension, of a flat value of BRL450 per household for all households with up-to-date information in the Single Registry and per capita income under half a minimum wage (BRL522.50).

In this case, the poorest 30 per cent of the population in Brazil would receive a minimum monthly income of at least BRL450 per household. Bolsa Família beneficiary households would receive an income security of almost BRL690 per month per household. After the end of the emergency benefit, beneficiary households would continue to receive, on average, something close to BRL240 per household (or BRL77 per capita) - a value that is 27 per cent higher than they currently receive.

The budget impact in 2020 would be of BRL68.6 billion. However, over 80 per cent of the additional costs would be temporary. The increased expenditures in 2021 would be very modest — only BRL11.6 billion, or less than 0.2 per cent of Brazil's 2019 GDP.

We also recommend that the emergency benefit be extended for as long as necessary to overcome the social crisis.

Considering the lagging purchasing power of current Bolsa Família benefits and the economic and social risks resulting from the COVID-19 pandemic, it seems a small price to pay to ensure a minimum level of well-being for the country's poorest people. 


\section{REFERENCES}

Banco Central do Brasil. (2020, May 15). Focus Relatório de Mercado. Brasília, DF: Bacen, 2020. Retrieved from https://www.bcb.gov.br/publicacoes/ focus

Gentilini, U. (2020, March 15). 14 countries have so far used some form of \#castransfer and \#basicincome program as \#coronavirus response. Twitter.com. Retrieved from https://twitter.com/Ugentilini/ status/1239184435402211336

Hoffman, R. (2013). Transferências de renda e desigualdade no Brasil (1995-2011). In T. Campello, \& M. NERI (Orgs.), Programa Bolsa Família - uma década de inclusão e cidadania. Brasília, DF: Instituto de Pesquisa Econômica Aplicada.

Instituto Brasileiro de Economia da Fundação Getulio Vargas. (2020, April). Boletim Macro. Rio de Janeiro, RJ: FGV. Retrieved from https:// portalibre.fgv.br/sites/default/files/2020-05/ boletimmacroibre_2004.pdf

Instituto de Pesquisa Econômica Aplicada. (2012). A década inclusiva (2001-2011): desigualdade, pobreza e políticas de renda. (Comunicados do Ipea, n. 155). Brasília, DF: Author.

Lindert, K., Linder, A., Hobbs, J., \& De La Brière, B. (2007). The nuts and bolts of Brazil's Bolsa Família Program: implementing conditional cash transfers in a decentralized context. (Social Protection Discussion Paper, n. 709). Washington, DC: The World Bank.

Ministério da Economia. (2020, May). Boletim Macrofiscal da SPE. Brasília, DF: Author. Retrieved from https://static.poder360.com.br/2020/05/ Apresentacao-Boletim-MacroFiscal-Maio.pdf

Osório, R. G., Soares, S., \& Souza, P. F. (2011). Erradicar a pobreza extrema: um objetivo ao alcance do Brasil (Texto para Discussão, n. 1619). Brasília, DF: IPEA.

Paiva, L. H., Cotta, T., \& Barrientos, A. Brazil's Bolsa Familia Programme. (2019). In M. Compton, \& P. T. Hart (Org.), Great Policy Successes (pp. 1-24). Oxford, UK: Oxford University Press. Retrieved from https:// doi.org/10.1093/oso/9780198843719.001.0001

Paiva, L. H., Souza, M. F., \& Nunes, H. M. P. (2020, March). Targeting in the Bolsa Familia programme from 2012 to 2018 based on data from the Continuous National Household Sample Survey. (One Pager, n. 436). Brasília, DF: Institute for Applied Economic Research. Retrieved from https://ipcig.org/pub/ eng/OP436_Targeting_in_the_Bolsa_FamIlia_ programme_from_2012_to_2018.pdf

Pena, C. R., Pinheiro, D. S., Albuquerque, P. H., \& Fernandes, L. M. (2015). A eficácia das transferências de renda: as tendências da desigualdade antes e depois do Programa Bolsa Família. Revista de Administração Pública, 49(4), 889-913. 


\section{Luis Henrique Paiva}

https://orcid.org/0000-0001-9197-7332

Ph.D. in Sociology. Coordinator for Studies and Research on Social Security of the Directorate for Social Policies and Studies of the Institute for Applied Economic Research. E-mail: luis.paiva@ipea.gov.br

\section{Pedro H. G. Ferreira de Souza}

https://orcid.org/0000-0002-5271-0165

Ph.D. in Sociology; Coordinator for Studies and Research on Information Management and for Studies on Poverty and Social Inequality of the Directorate for Social Policies and Studies of the Institute for Applied Economic Research. E-mail: pedro.ferreira@ipea.gov.br

\section{Letícia Bartholo}

(D)

https://orcid.org/0000-0001-8340-0074

M.Sc. in Demography. Expert in Public Policies and Governmental Management, working at the Directorate for Social Policies and Studies of the Institute for Applied Economic Research. E-mail: leticia.bartholo@ipea.gov.br

\section{Sergei Soares}

https://orcid.org/0000-0003-4806-0267

Ph.D. in Economics. Coordinator for Studies on Institutions and International Governance of the Directorate for Economic Studies and Relations and International Policies of the Institute for Applied Economic Research. E-mail: sergei.soares@ipea.gov.br 
RAP | Avoiding the poverty pandemic: the potential of the Bolsa Família program and the Single Registry for Social Programs to face the COVID-19 pandemic

\section{APPENDIX}

\section{TABLE A RESULTS OF THE 56 SIMULATED SCENARIOS}

\begin{tabular}{|c|c|c|c|c|c|c|}
\hline \multirow{2}{*}{ Number } & \multirow{2}{*}{ Scenario } & \multicolumn{2}{|c|}{ Coverage (millions) } & \multirow{2}{*}{$\begin{array}{l}\text { Cost per month } \\
\text { (BRL billion) }\end{array}$} & \multicolumn{2}{|c|}{ Average monthly benefit (BRL) } \\
\hline & & Households & People & & Per household & Per person \\
\hline 1 & Benchmark & 13.761 & 42.732 & 2.586 & 188 & 61 \\
\hline 2 & $A$ & 15.482 & 47.658 & 2.835 & 183 & 59 \\
\hline 3 & B1 & 13.761 & 42.732 & 3.108 & 226 & 73 \\
\hline 4 & B2 & 13.761 & 42.732 & 3.446 & 250 & 81 \\
\hline 5 & B3 & 13.761 & 42.732 & 3.798 & 276 & 89 \\
\hline 6 & C1 & 21.137 & 63.596 & 5.756 & 272 & 91 \\
\hline 7 & $\mathrm{C} 2$ & 21.137 & 63.596 & 8.927 & 422 & 140 \\
\hline 8 & C3 & 21.137 & 63.596 & 12.097 & 572 & 190 \\
\hline 9 & C4 & 21.137 & 63.596 & 5.766 & 273 & 91 \\
\hline 10 & C5 & 21.137 & 63.596 & 8.945 & 423 & 141 \\
\hline 11 & C6 & 21.137 & 63.596 & 12.125 & 574 & 191 \\
\hline 12 & $A+B 1$ & 16.045 & 49.488 & 3.474 & 217 & 70 \\
\hline 13 & $A+B 2$ & 16.221 & 50.150 & 3.873 & 239 & 77 \\
\hline 14 & $A+B 3$ & 16.605 & 51.599 & 4.314 & 260 & 84 \\
\hline 15 & $A+C 1$ & 21.137 & 63.596 & 6.005 & 284 & 94 \\
\hline 16 & $\mathrm{~A}+\mathrm{C} 2$ & 21.137 & 63.596 & 9.176 & 434 & 144 \\
\hline 17 & $A+C 3$ & 21.137 & 63.596 & 12.346 & 584 & 194 \\
\hline 18 & $A+C 4$ & 21.137 & 63.596 & 6.015 & 285 & 95 \\
\hline 19 & $A+C 5$ & 21.137 & 63.596 & 9.194 & 435 & 145 \\
\hline 20 & $A+C 6$ & 21.137 & 63.596 & 12.374 & 585 & 195 \\
\hline 21 & $\mathrm{~B} 1+\mathrm{C} 1$ & 21.137 & 63.596 & 6.278 & 297 & 99 \\
\hline 22 & $\mathrm{~B} 1+\mathrm{C} 2$ & 21.137 & 63.596 & 9.449 & 447 & 149 \\
\hline 23 & $\mathrm{~B} 1+\mathrm{C} 3$ & 21.137 & 63.596 & 12.619 & 597 & 198 \\
\hline 24 & $\mathrm{~B} 1+\mathrm{C} 4$ & 21.137 & 63.596 & 6.288 & 297 & 99 \\
\hline 25 & $\mathrm{~B} 1+\mathrm{C} 5$ & 21.137 & 63.596 & 9.467 & 448 & 149 \\
\hline 26 & $\mathrm{~B} 1+\mathrm{C} 6$ & 21.137 & 63.596 & 12.647 & 598 & 199 \\
\hline 27 & $\mathrm{~B} 2+\mathrm{C} 1$ & 21.137 & 63.596 & 6.616 & 313 & 104 \\
\hline 28 & $\mathrm{~B} 2+\mathrm{C} 2$ & 21.137 & 63.596 & 9.787 & 463 & 154 \\
\hline
\end{tabular}


RAP | Avoiding the poverty pandemic: the potential of the Bolsa Família program and the Single Registry for Social Programs to face the COVID-19 pandemic

\begin{tabular}{|c|c|c|c|c|c|c|}
\hline \multirow{2}{*}{ Number } & \multirow{2}{*}{ Scenario } & \multicolumn{2}{|c|}{ Coverage (millions) } & \multirow{2}{*}{$\begin{array}{l}\text { Cost per month } \\
\text { (BRL billion) }\end{array}$} & \multicolumn{2}{|c|}{ Average monthly benefit (BRL) } \\
\hline & & Households & People & & Per household & Per person \\
\hline 29 & $\mathrm{~B} 2+\mathrm{C} 3$ & 21.137 & 63.596 & 12.957 & 613 & 204 \\
\hline 30 & $\mathrm{~B} 2+\mathrm{C} 4$ & 21.137 & 63.596 & 6.626 & 313 & 104 \\
\hline 31 & $\mathrm{~B} 2+\mathrm{C} 5$ & 21.137 & 63.596 & 9.805 & 464 & 154 \\
\hline 32 & $\mathrm{~B} 2+\mathrm{C} 6$ & 21.137 & 63.596 & 12.985 & 614 & 204 \\
\hline 33 & $\mathrm{~B} 3+\mathrm{C} 1$ & 21.137 & 63.596 & 6.969 & 330 & 110 \\
\hline 34 & $\mathrm{~B} 3+\mathrm{C} 2$ & 21.137 & 63.596 & 10.139 & 480 & 159 \\
\hline 35 & $\mathrm{~B} 3+\mathrm{C} 3$ & 21.137 & 63.596 & 13.310 & 630 & 209 \\
\hline 36 & $\mathrm{~B} 3+\mathrm{C} 4$ & 21.137 & 63.596 & 6.978 & 330 & 110 \\
\hline 37 & $\mathrm{~B} 3+\mathrm{C} 5$ & 21.137 & 63.596 & 10.158 & 481 & 160 \\
\hline 38 & $\mathrm{~B} 3+\mathrm{C} 6$ & 21.137 & 63.596 & 13.338 & 631 & 210 \\
\hline 39 & $\mathrm{~A}+\mathrm{B} 1+\mathrm{C} 1$ & 21.137 & 63.596 & 6.644 & 314 & 104 \\
\hline 40 & $\mathrm{~A}+\mathrm{B} 1+\mathrm{C} 2$ & 21.137 & 63.596 & 9.815 & 464 & 154 \\
\hline 41 & $\mathrm{~A}+\mathrm{B} 1+\mathrm{C} 3$ & 21.137 & 63.596 & 12.985 & 614 & 204 \\
\hline 42 & $\mathrm{~A}+\mathrm{B} 1+\mathrm{C} 4$ & 21.137 & 63.596 & 6.654 & 315 & 105 \\
\hline 43 & $A+B 1+C 5$ & 21.137 & 63.596 & 9.833 & 465 & 155 \\
\hline 44 & $\mathrm{~A}+\mathrm{B} 1+\mathrm{C} 6$ & 21.137 & 63.596 & 13.013 & 616 & 205 \\
\hline 45 & $\mathrm{~A}+\mathrm{B} 2+\mathrm{C} 1$ & 21.137 & 63.596 & 7.043 & 333 & 111 \\
\hline 46 & $\mathrm{~A}+\mathrm{B} 2+\mathrm{C} 2$ & 21.137 & 63.596 & 10.214 & 483 & 161 \\
\hline 47 & $\mathrm{~A}+\mathrm{B} 2+\mathrm{C} 3$ & 21.137 & 63.596 & 13.384 & 633 & 210 \\
\hline 48 & $\mathrm{~A}+\mathrm{B} 2+\mathrm{C} 4$ & 21.137 & 63.596 & 7.053 & 334 & 111 \\
\hline 49 & $\mathrm{~A}+\mathrm{B} 2+\mathrm{C} 5$ & 21.137 & 63.596 & 10.233 & 484 & 161 \\
\hline 50 & $\mathrm{~A}+\mathrm{B} 2+\mathrm{C} 6$ & 21.137 & 63.596 & 13.412 & 635 & 211 \\
\hline 51 & $\mathrm{~A}+\mathrm{B} 3+\mathrm{C} 1$ & 21.137 & 63.596 & 7.484 & 354 & 118 \\
\hline 52 & $\mathrm{~A}+\mathrm{B} 3+\mathrm{C} 2$ & 21.137 & 63.596 & 10.655 & 504 & 168 \\
\hline 53 & $\mathrm{~A}+\mathrm{B} 3+\mathrm{C} 3$ & 21.137 & 63.596 & 13.825 & 654 & 217 \\
\hline 54 & $\mathrm{~A}+\mathrm{B} 3+\mathrm{C} 4$ & 21.137 & 63.596 & 7.494 & 355 & 118 \\
\hline 55 & $A+B 3+C 5$ & 21.137 & 63.596 & 10.674 & 505 & 168 \\
\hline 56 & $\mathrm{~A}+\mathrm{B} 3+\mathrm{C} 6$ & 21.137 & 63.596 & 13.853 & 655 & 218 \\
\hline
\end{tabular}

Source: Elaborated by the authors. 